\title{
Health and Family Communication: Exploring Concept and Issues
}

\author{
Eko Hero \\ ekohero@comm.uir.ac.id \\ Faculty of Communications Science - Universitas Islam Riau \\ Dini Sundari \\ dinisundari1996@gmail.com \\ Faculty of Communications Science - Universitas Islam Riau
}

\begin{abstract}
The phenomenon of early age marriage has occurred in many places over the world including in Indonesia. What is more, the maternal mortality rate and other risks of health reproductive had been also increased. Numerous of argumentations that the pregnancy at a young age will create a higher chance of females having a bunch of children and a higher risk of death of the mother and child. Likewise, analyzing important issues regarding marriage at a young age is very important to provide a deep scientific understanding. Through a qualitative approach, this study aims to explore the conceptual issues about health communication which involves reproductive health, negotiation, early-age marriage, and family communication. Health communication is the role of communication to disseminate health information in the form of communication with patients, family, and community. Reproductive health is about all matters related to a reproductive system including its functions and processes. Negotiation concerns the interactive process done to reach an agreement that involves two or more people who have different perspectives and willing to reach the same resolution together. The early-age marriage is a formal or non-formal marriage done below 18 years of age. Family communication is a communication activity done in a family in which a process of exchanging meaning includes delivering emotion among its members.
\end{abstract}

Keywords: health; communication; reproduction; family communication, early-age marriage; reproductive health.

\section{INTRODUCTION}

Marriage is a commitment between heterosexual men and women to validate their relationship that has a value as a form of worship. Allah SWT has created the earth and everything on it in pairs as the symbol of his greatness. Besides that, marriage is also a form of the unification of two individuals into the same purpose, which is the lasting happiness with their own spouses. The unification of individuals as the representation of the marriage relationship based on sacred ties. Committing into marriage will surely be followed by the forming of positive values which required as the social, family, and religious value. The purpose of it is the marriage will give benefit both the individuals and their social environment.

Referring to the data from the United Nations Populations Fund (UNFPA), a few countries with a high amount of early-age marriage such as Nigeria, Chad, Malawi, Bangladesh, and India. UNICEF also highlighted the early-age marriage in Indonesia where 
$27,4 \%$ of females in Indonesia got married before the age of 20. Take what happened in five provinces in Indonesia as an example, the ratio (of early-age marriage) is above $30 \%$. Sulawesi with the ratio of 34\%, South Kalimantan with 33, 68\%; Central Kalimantan 33, 56\%; West Kalimantan 32, 21\% and Central Sulawesi 31, 91\%. (UNFPA, 2012)

The problem of early marriage becomes very important to note, even some parties have the right to play a role to tackle the problem of early marriage, and today there is a village in Indonesia that is a very positive response to this early marriage. Because they assume that early marriage is a tradition from the ancestors that must be preserved down and down. One of the Districts that make early marriage as existence is in the District of Seberang Ulu I, Palembang City. There are very many marriages that occur at an early age, even it has become a habit of the people there. It is as if the laws that have governed them are ignored without touching the minds of the people (Muntamah et al, 2019).

The issue of the problem is how far the negotiation done by the teens when they decided to get married at such a young age. In the marriage law, it is mentioned that "marriage is only allowed if the male is 19 years old and the female is already 16 years old". At this age, the transition and the flaming youth to their adolescent usually begin to appear and they are in the process of finding their self-identity. So that a marriage with the limitation age of 19 for males and 16 for females is now rather irrelevant if it is categorized as a mature marriage, even if from the perspective of law, it is not crossing any rules in the marriage law.

In addition, the variety of perceptions and paradigms about the advantage and disadvantages of young-age marriage, forcing the intensity and quality of the communication in a family. Getting married is not about the momentum, but it is a part of the process of humans live. In accordance with that, this article is going to comprehensively discuss conceptual issues related to health communication, reproductive right, negotiation, early-age marriage, family communication.

\section{METHODOLOGY}

This study was done by using a qualitative method. Pathak, V., Jena, B., \& Kalra, S. (2013) stated that the qualitative method is used to understand people's beliefs, experiences, attitudes, behavior, and interactions. While according to Moleog (2007) qualitative methods as an inquiry procedure to yield descriptive data based on written or oral words of people and behavior that can be observed holistically. This study conducted based on the library research which the data acquired from secondary data such as books, research reports, and scientific journals.

\section{HEALTH COMMUNICATION}

Health communication is an effort of sharing information by using the communicative strategy to inform and convince society to higher their level of health in the society itself (Jackson et al, 998). According to (Backer et al, 1992) the activity of health communication could be effective if it takes the aspect of accuracy, availability, balance, and harmony of information being presented and oriented around the recipients.

Health communication is a systematic effort to positively influence the health behaviors of individuals and communities, using various principles and methods of communication both interpersonal communication, and mass communication. In addition, health communication is also understood as a study that studies how to use communication strategies to disseminate 
health information that can affect individuals and communities in order to make the right decisions regarding health management.

There are several forms of health communication context which consist of:

1. Health communication with patients / sufferers.

Health communication with patients or sufferers includes information relating to individual health conditions, information on how to maximize care and how to provide therapy. Health communication in patients / sufferers is more therapeutic, which means facilitating the healing process. According to (Purwanto in Damaiyanti, 2008) therapeutic health communication has the goal of: a) Help patients reduce the burden of feelings and thoughts and help patients take action to change the situation when needed by patients. b) Help reduce patient doubts and help patients take effective actions. Problems in the process of communication that often occurs between patients-health experts is the use of vocabulary that is too long, difficult to understand, complex, and the use of medical terms that are often not understood by patients. Therefore, if communication between a health professional and a patient is seen as an interaction between two individuals, it becomes important that both parties speak the same "language", have the same belief (Eg. the belief that the patient's illness can be cured) and the same - agree on the content of the discussion in the consultation and both parties understand the final results of the consultation stage.

2. Health communication with the family

Health communication with patients and families is an important part of medical care. Effective communication is essential because the patient can understand his situation and the family can understand the condition of his family members who are sick. Failure to communicate health information to the patient and the family can result in a patient's misunderstanding of the results of the test being undertaken. If the family also cannot understand health issues related to a family member who is sick, it is likely that the family will not give full support to the family member who is sick. For example, if the family is not informed of the symptoms to watch out for, psychological reactions and emotional reactions (the sufferer is irritable, sensitive and easily offended) that may arise in connection with the condition of the sick, can be disturbed harmony of communication within the family.

3. Health communication with the community

Health communication for the community is more directed to the form of health promotion. Health promotion is not only the process of community awareness in terms of providing and increasing knowledge in the health sector. Health promotion is a health program designed to bring about improvements in behavior change, both within the community and the organizational environment. To be able to realize health promotion, we need a good strategy. Strategy is the means used in achieving what is desired in health promotion. According to Mubarak and Chayatin (2008), this strategy is needed in realizing health promotion, and is reflected in three steps:

a) Advocacy. It is an activity of providing health information assistance to the public through decision makers and policy makers in the health sector. 
b) Social support. Health promotion will be easy to do if it has the support of various elements in the community. Public support includes informal elements (religious and traditional leaders) and formal elements (health workers, government officials).

c) Community empowerment (empowerment community). Community empowerment is needed so that people gain the ability to maintain and improve health. These efforts can be carried out through health education. Developments that occur in the midst of the community in communicating health issues have experienced significant changes. This change was marked by an increase in access to health information, increased community members' attention to health issues and increasing demands for quality health information (Rahmadiana, 2012).

In this context, parents are the person who is counted to be having the high credibility in informing the reproductive health to their children, it indeed needs a good strategy and technique to convey the messages that could be useful to their children once they become the wives.

\section{REPRODUCTIVE HEALTH}

The physical and emotional condition and also the social welfare and the inexistence of disease related to the process, function, and system of human reproduction in every level of life. The reproductive health implies that every person could have and enjoy safe sex life and they have the ability to reproduce, and to have their freedom of deciding when and how often they want to reproduce (Hidayana, 2004).

Reproductive health is an important thing considering reproduction is a means to give birth to the next generation of the nation. Reproductive health has three components, namely the ability to procreate, regulate and maintain fertility, and enjoy a responsible sexual life. Even the 1994 Population Conference in Cairo has defined the definition of reproductive health in a sense.

"Reproductive health is a state of complete physical, mental and social well-being and not merely the absence of disease or infirmity, in all matters relating to be reproductive system and to its functions and processes. Reproductive health therefore implies that people are able to have a satisfying and safe sex life and that they have the capability to reproduce and the freedom to decide if, when and how often to do so. Implicit in this last condition are the right of men and women to be informed and to have access to safe, effective, off or dabble and acceptable methods of family planning of their choice, as well as other methods of their choice for regulation of fertility which are not against the law, and the right of access to appropriate health-care services that will enable women to go safely through pregnancy and childbirth and provide couples with the best chance of having a healthy infant. In line with the above definition of reproductive health, reproductive health care is defined as the constellation of methods, techniques and services that contribute to reproductive health and well-being by preventing and solving reproductive health problems. It also includes sexual health, the purpose of which is the enhancement of life and personal relations, and not merely counselling and care related to reproduction and sexually transmitted diseases."

Viewed from the definition above, reproductive health is not only oriented towards preventing and maintaining reproductive problems but also includes sexual health 
(Wulandari, 2015). In order to protect their reproduction health, women have the rights to their reproductive health such as:

a. Rights to have information and education about health and reproduction.

b. Rights to get the service and protection of reproductive health.

c. Rights to have freedom of thinking about the service of reproductive health.

d. Rights to be protected over the death from pregnancy

e. Rights to decide the amount and gap of children's birth

f. Rights over freedom and safety related to their reproductive life.

g. Rights to be free from abuse and bad treatment including protection from rape, abuse, torture, and sexual harassment.

h. Rights to be informed about the advance of knowledge related to reproductive health.

i. Rights over the service and life of their reproduction.

j. Rights to build and plan a family

k. Rights to be free of every kind of discrimination in the family and reproductive life.

1. Rights to have the freedom to gather and participate in politics related to health reproduction. (Widyastuti et al, 2009).

\section{NEGOTIATION}

Negotiation is also referred to as an interactive process done to reach an agreement. This process involves two or more people that have different perspectives but willing to reach the same resolution together (McGuire, 2004). While Jackman (2004) mentioned that a negotiation is a form of process, a method to achieve the agreement on a certain problem that is discussed or debated. Based on those explanations above, it could be concluded that negotiation is a communication process where two people or more with different purposes doing the feedback process that includes the exchange of two or more people to achieve the mutual agreement that benefits everyone.

Referring to the conclusion above, it can be concluded that the negotiation over reproductive health is a process, method to achieve agreement about how every human has their safe sex life related to the process, function, and system of their reproduction. To achieve the agreement, there are stages needed to take before making a decision. Such as The Stage of Preparation of Negotiation (understanding and knowing the problem, deciding the side, the limitation of the bargain, delivery of issues, and facts). The Step of Informational Exchange, the bargaining stage, and the closing commitment.

\section{EARLY-AGE MARRIAGE}

The early-age marriage is a formal or non-formal marriage done by those below 18 years of age (UNICEF, 2014). It is a bond created by a person at their young age or in puberty and also known as the early-age marriage. According to the Marriage Law, No. 1 Article 1 in 1974 stated that marriage is an emotional and physical bond between a male and female to create a happy family that lasts based on the Belief in The Almighty God. Then explained more in Article 7 paragraph 1 about how marriage is only permitted when the male reaches the age of 19 (nineteen) and the female being 16 (sixteen). In line with the definition of marriage law, Landung et al (2009) explained that marriage done in the early-age is actually violating the rules of marriage law itself that is called the early-age marriage.

While Al Ghifari takes the early-age marriage is a marriage that is done in the teen age10. In this case, the teens are those between the ages of 10-19 and not married. A person 
who has created the physical and emotional bond between male and female as husband and wife with the purpose of having a family, done in under the law and or tradition/belief could also be called marriage. If marriage was done by a person who is relatively young it still could be considered as the early-age marriage. This young age in here is the age of puberty around 10-19. So then a teenager who is around 10-19 years old that already created the emotional and physical bond as husband-wife with the purpose of having a family could be called as the early-age marriage. If so, then the researcher concluded that the early-age marriage is the divine bond between male below 19 and female below 16 years old. There are numerous factors that caused a person to take a decision to be married at such a young age or parents that get their children married at a young age. Such as the educational factor (Sarwono, 2007), and the family financial factor (Alfiyah, 2010), and then self-factor (Sakdiyah et al 2013).

In terms of accident factors, such as the occurrence of pregnancy out of wedlock, because children have relationships that violate the norm, forcing them to have an early marriage, in order to clarify the status of the child conceived, perpetuate the relationship of early marriage in this case deliberately done all that has been prepared.

In certain families, it can be seen that some have a tradition or habit of marrying off their children at a young age. So that children in the family will automatically follow the tradition. Finally, because of local customs for certain communities believe increasingly add to the percentage of early marriage in Indonesia. For example, the belief that not to refuse someone's proposal to his daughter even though he was 16 years old (Syufiyah, 2018).

Besides those factors above, the researcher also noticed the trend of early-age marriage is also affected by some shows on the television, knowledge from religious teaching, and the teenage social environment. Because it is not uncommon that those who got married in their youth are those who have taken high education. The establishment of a family of early marriage is prone to problems such as domestic problems in early marriage Gender inequality is a consequence of child marriage. The bride and groom have a limited capacity to voice opinions, negotiate sexual desire, use contraceptives, and have children. Likewise, with other domestic aspects. The dominance of couples often leaves children vulnerable to domestic violence. Domestic violence is highest in India, especially among women aged 18 years. Women who marry at a younger age often experience violence. Children who face domestic violence tend not to fight, as a result they also do not get the fulfillment of a sense of security both socially and financially. In addition, marriages with distant adolescents increase the risk of the family becoming incomplete due to divorce, or being widowed because the spouse dies (Fadlyana et al, 2016).

There are several things that become the impact of someone having an early marriage both physically or biologically which consists of:

a) Teenagers who become pregnant will more easily suffer from anemia while pregnant and giving birth, one of the causes of high maternal and infant mortality.

b) Missing the opportunity to taste higher education. In certain conditions, children who engage in early marriage tend not to pay attention to their education, especially when getting married directly get offspring, he will be busy taking care of children and their families, so this can prevent him from continuing his studies to a higher level. But this can be minimized with full family support, and there is help in child care, will be able to minimize early marriage couples to be able to continue their studies. 
c) Interaction with the peer environment is reduced. However the status of both husband and wife also contributes in social interaction with the environment. For early marriage couples, this can be influential in dealing with peers. They will feel awkward or reluctant to get along with their peers. They are in an uncertain condition in social status, because when associating with parents, their relationship is still a teenager, and vice versa, want to play with peers who are teenagers, in fact they have the status of husband and wife. This will cause them to be justified, that is, wrong adjustment. Then they must be able to adapt to their social environment well.

d) Narrow opportunities for employment opportunities that automatically perpetuate poverty (low family economic status due to lack of education). Early marriage does not only affect the person who performs it but also has an impact on the child, namely: 1) Born with a low weight, as the main cause and even high maternal and infant mortality. 2) Injury at birth. 3) Birth complications that have a high impact on mortality. Not only does it affect the children born, the construction of early marriages also impacts the family being fostered: 1) Violence against a wife because of the immature level of thinking for the young couple. 2) Economic difficulties in the household. 3) Lack of knowledge about marital institutions.

e) Bad correlation (re-establishing) with family. Religious foundation in religious guidance services for prospective couples (Mubasyaroh, 2016).

\section{FAMILY COMMUNICATION}

Family communication has a high dependency and complexity. As what has been explained that the family is in the primary group so the group of communication according to Charles Horton Cooley in Rohim (2009) communication in the primary group of characteristics as follows: first, the quality of communication in the primary group is usually in-depth and wide, (which taken as) going through the deepest part of our personality that is hidden, and revealing the backstage factors. While wide means there are only a few problems that caused the challenge and ways to communicate. In the primary group, we reveal the personal problem by using the verbal and also nonverbal symbols. Secondly, the primary group is personal, the most important to us is who they are not what they are.

The relation inside of the primary group is unique and irreplaceable. For example, the relation of the mother and the child. Thirdly, in the primary group, the communication concerns more on the aspect of relation, rather than the contents' aspect. The communication is done to protect the good relationship, and the content of the communication is not as essential. Different from the second group where the content aspect is rather more important than the relation aspect. Fourth, the primary group usually conveys ideas in more expressive ways, and in the informal ways.

Discussing the family as the primary group then the communication is one of the most important aspects that is used to measure a relation between family members. Galvin and Brommel (1986) used the following framework to explain about the family communication: We view the family as a system in which communication regulates cohesion and adaptability by a flow of message patterns through a defined network of evolving interdependent relationships. From that definition that we could see a family as a system that is built from a group of people that are related to one and another, the individuals in it could face changes and affecting the system in the family. The family is defined as the result of a primary 
socialization process for a child where in time the child will be delivered to enter the wider community (social structure). Meanwhile, according to Hildred (Geertz (1983), the family is a place of intensive and continuous socialization and transformation of moral, ethical, and social values among its members from generation to generation (Setyowati, 2013).

The communication done in a family is a process of exchanging meaning and that family could grow its capacity as a platform to deliver their emotion to its members. Because the family members interact with one another with the high frequency and repeatedly, then the communication done is more predicted and one another interacted in specific ways. The connection between the decisions of getting the children married the early-age of course needing the communication specifically for the family only.

\section{CONCLUSION}

Related to the issue of health communication, there are many main concepts that must be understood by the public. However, in this discussion only focuses on five main concepts. They are Health communication relates to disseminating health information in the form of communication with patients, family, and community. Reproductive health relates to a reproductive system, involves its functions and processes. Negotiation concerns to reach an agreement about health among two or more people who have different perspectives for the same resolution. The early-age marriage is about the marriage practice for those whose age I8 years old. Family communication is a communication activity done among its members.

\section{ACKNOWLEDGEMENT}

We would like to thank to BKKBN (Badan Kependudukan dan Keluarga Berencana Nasional) of Riau Province for providing the opportunity for researchers to share the necessary information relating to the research themes that researchers conducted.

\section{REFERENCES}

Alfiyah. (2010). Sebab-sebab dalam Pernikahan Dini. retrieved from http//alfiyah23.student.umm.ac.id.

Backer, T. E., Rogers, E., \& Sopory, P. (1992). Designing health communication campaigns: What works? Sage Publications.

Damaiyanti, M. (2008). Komunikasi terapeutik dalam praktik keperawatan. Bandung: Refika Aditama.

Duffy, B. K., \& Jackson, L. D. (Eds.). (1998). Health communication research: A guide to developments and directions. Greenwood.

Fadlyana, E., \& Larasaty, S. (2016). Pernikahan usia dini dan permasalahannya. Sari Pediatri, 11(2), 136-41. http://dx.doi.org/10.14238/sp11.2.2009.136-41

Faizah Abdul Majid, Zalizan Jelas \& Norzaini Azman. (2002). Selected Malaysian Adult Learners' Academic Reading Strategies: A Case Study. Retrieved August 16, 2005 from http://face.stir.ac.uk/Majidp61.htm

Galvin, K. M., \& Brommel, B. J. (1986). Family communication. Glenview, IL: Scott, Foresman and Company.

Hidayana, I. M. (2004). Seksualitas dan gender: Sebuah pengantar. Seksualitas: Teori dan realitas. Jakarta: Program Gender dan Seksualitas FISIP UI.

Jackman, A. (2004). How to negotiate. ESENSI. 
Landung, J., Thaha, R., \& Abdullah, A. Z. (2009). Studi kasus kebiasaan pernikahan usia dini pada masyarakat Kecamatan Sanggalangi Kabupaten Tana Toraja. Jurnal MKMI, 5(4), 89-94.

Lexy J. Moleong (2009) Metodologi Penelitian Kualitatif. Bandung: PT. Remaja Rosdakarya

McGuire, R. (2004). Negotiation: an important life skill. Pharmaceutical journal, 273(7306), 23-25.

Mubarak, W. I., \& Chayatin, N. (2008). Buku ajar kebutuhan dasar manusia: Teori dan aplikasi dalam praktik. Jakarta: Media Aesculapius.

Mubasyaroh, M. (2016). Analisis Faktor Penyebab Pernikahan Dini Dan Dampaknya Bagi Pelakunya. YUDISIA: Jurnal Pemikiran Hukum dan Hukum Islam, 7(2), 385-411. http://dx.doi.org/10.21043/yudisia.v7i2.2161

Muntamah, A. L., Latifiani, D., \& Arifin, R. (2019). Pernikahan dini di Indonesia: Faktor dan peran pemerintah (Perspektif penegakan dan perlindungan hukum bagi anak). Widya Yuridika, 2(1), 1-12.

Nurhajati, L., \& Wardyaningrum, D. (2014). Komunikasi Keluarga dalam Pengambilan Keputusan Perkawinan di Usia Remaja. Jurnal Al-Azhar Indonesia Seri Pranata Sosial, 1(4), 236-248.

Ozirney, H. A. (2007). Knot Happy: How Your Marriage Can Be. Tate Publishing.

Pathak, V., Jena, B., \& Kalra, S. (2013). Qualitative research. Perspectives in clinical research, 4(3).

Rahmadiana, M. (2012). Komunikasi kesehatan: Sebuah tinjauan. Jurnal Psikogenesis, 1(1), 88-94. https://doi.org/10.24854/jps.v1i1.38

Rohim, S. (2009). Teori komuniksai: perpektif, ragam dan aplikasi. Rineka Cipta.

Ruben, Brent D., Lea P. Stewart. (2006). Communication and Human Behavior. $5^{\text {th }}$ Ed. USA: Pearson Education, Inc.

Sakdiyah, H., \& Ningsih, K. (2013). Mencegah pernikahan dini untuk membentuk generasi berkualitas (Preventing early-age marriage to establish qualified generation). Masyarakat, Kebudayaan dan Politik, 26(1), 35-54.

Sarwono, S. (2007). Psikologis Remaja. Jakarta: PT Raja Grafindo Persada.

Setyowati, Y. (2013). Pola Komunikasi Keluarga Dan Perkembangan Emosi Anak (Studi Kasus Penerapan Pola Komunikasi Keluarga Dan Pengaruhnya Terhadap Perkembangan Emosi Anak Pada Keluarga Jawa). Jurnal Ilmu Komunikasi, 2(1), 103135.

Shahizah Ismail Hamdan. (2008). Science fiction minds and bodies: Reconsidering the borders of human subjectivity. Paper presented at The Novel and Its Borders. A Conference at the Centre for the Novel. Scotland: University of Aberdeen, July.

Shufiyah, F. (2018). Pernikahan Dini Menurut Hadis dan Dampaknya. Jurnal Living Hadis, 3(1), 47-70. https://doi.org/10.14421/livinghadis.2017.1362

Unicef. (2014). A study on early marriage in Jordan 2014. Amman: UNICEF.

United Nations Population Fund. (2012). Marrying Too Young: End child marriage. New York: UNFPA.

Widyastuti, Y., Rahmawati, A., \& Purnamaningrum, Y. E. (2009). Kesehatan reproduksi. Yogyakarta: Fitramaya, 26(66), 2.

Wulandari, D. (2015). Studi Kritis Konsep Kesehatan Reproduksi Wanita Dalam Convention on The Elimination Of All Forms Discrimination Against Women (Cedaw) Menurut Tinjauan Islam. Profetika: Jurnal Studi Islam, 16(1), 36-45. 


\section{ABOUT THE AUTHORS}

Eko Hero is currently a Doctoral Student at Islamic Communication Broadcasting Departement Universitas Islam Negeri Sumatra Utara. He is also a lecturer at Faculty of Communications Science - Universitas Islam Riau. Pekanbaru, Indonesia.

Dini Sundari is an alumnus of Bachelor Degree at Faculty of Communications ScienceUniversitas Islam Riau. Pekanbaru, Indonesia. 